\title{
Alpine tectonic wedging and crustal delamination in the Cantabrian Mountains (NW Spain)
}

\author{
Jorge Gallastegui ${ }^{1}$, Javier A. Pulgar ${ }^{1}$, and Josep Gallart ${ }^{2}$ \\ ${ }^{1}$ Departamento de Geología, Universidad de Oviedo, Jesús Arias de Velasco s/n, 33005 Oviedo, Spain \\ ${ }^{2}$ Instituto Ciencias Tierra Jaume Almera-CSIC, Lluís Solé Sabarís s/n, 08028 Barcelona, Spain \\ Correspondence to: Jorge Gallastegui (jorge@ geol.uniovi.es)
}

Received: 28 January 2016 - Published in Solid Earth Discuss.: 11 February 2016

Revised: 7 June 2016 - Accepted: 15 June 2016 - Published: 15 July 2016

\begin{abstract}
The Cantabrian Mountains have been interpreted as a Paleozoic basement block uplifted during an Alpine deformation event that led to the partial closure of the Bay of Biscay and the building of the Pyrenean range in the Cenozoic. A detailed interpretation of deep seismic reflection profile ESCIN-2 and the two-dimensional seismic modelling of the data allowed us to construct a N-S geological cross section along the southern border of the Cantabrian Mountains and the transition to the Duero Cenozoic foreland basin, highlighting the Alpine structure. The proposed geological cross section has been constrained by all geophysical data available, including a 2-D gravity model constructed for this study as well as refraction and magnetotelluric models from previous studies. A set of south-vergent thrusts dipping 30 to $36^{\circ}$ to the north, cut the upper crust with a ramp geometry and sole in the boundary with the middle crust. These thrusts are responsible for the uplift and the main Alpine deformation in the Cantabrian Mountains. A conspicuous reflective Moho shows that the crust thickens northwards from the Duero basin, where subhorizontal Moho is $32 \mathrm{~km}$ deep, to $47 \mathrm{~km}$ in the northernmost end of ESCIN-2, where Moho dips to the north beneath the Cantabrian Mountains. Further north, out of the profile, Moho reaches a maximum depth of $55 \mathrm{~km}$, according to wide-angle/refraction data. ESCIN-2 indicates the presence of a tectonic wedge of the crust of the Cantabrian margin beneath the Cantabrian Mountains, which is indented from north to south into the delaminated Iberian crust, forcing its northward subduction.
\end{abstract}

\section{Introduction}

The Cantabrian Mountains constitute an E-W-oriented range that extends more than $250 \mathrm{~km}$ and is the western extension of the Pyrenean range (Fig. 1). The tectonic history of the area is long and complex, spanning from lower Paleozoic to upper Miocene times. The eastern end of the range has been interpreted as a Paleozoic basement block, which is part of the Variscan chain of western Europe, that was later uplifted and slightly deformed during the Alpine cycle (Alonso et al., 1996). The studied area is located in the outermost section of the Iberian Variscan foreland thrust and fold belt, where Variscan deformation took place under shallow conditions with scarce metamorphism and cleavage (Matte, 1991, Pérez-Estaún and Bastida, 1990). The wellknown Variscan structure of the mountain range has been studied for a long time (e.g. Julivert, 1971; Pérez-Estaún et al., 1988; Dallmeyer and Martínez-García, 1990; Alonso et al., 2009), and more recent studies have focused on the Alpine structure (Alonso et al., 1996; Pulgar et al., 1996, 1999; Gallastegui, 2000; Gallastegui et al., 2002, MartínGonzález et al., 2011; Pedreira et al., 2015). The Alpine history is directly related to the post-Variscan evolution of the North Iberian Margin, which started by a Permo-Triassic rifting stage that was followed by an approximately N-S extensional episode, triggered by the opening of the Atlantic Ocean and the Bay of Biscay during Late Jurassic and Early Cretaceous times. The basins that developed in the passive margin remained stable during the sea-floor spreading phase that took place in the Bay of Biscay in the Upper Cretaceous (Martínez-García, 1982; Vegas and Banda, 1982; Boillot et al., 1984; Boillot and Malod, 1988; Verhoef and Srivas- 


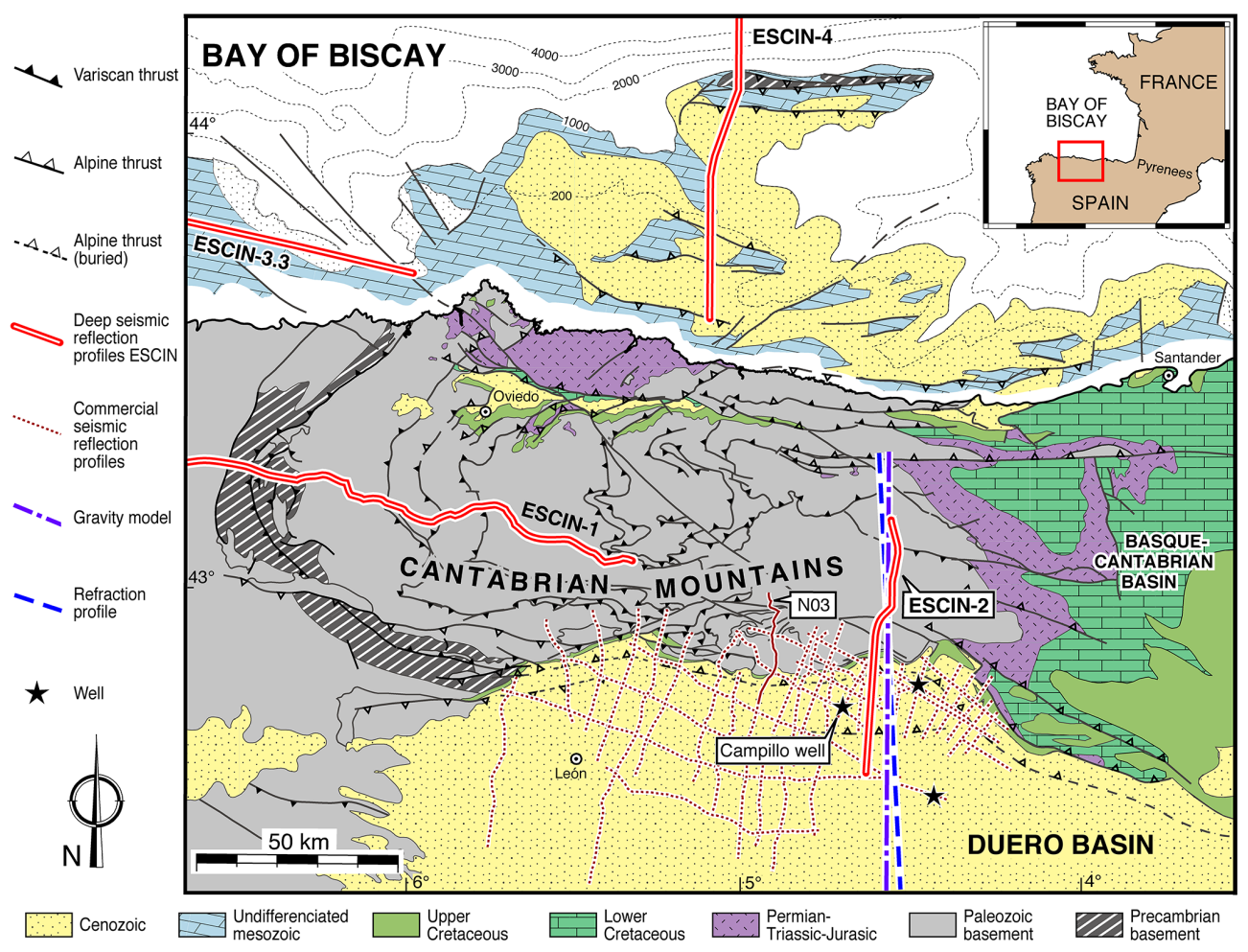

Figure 1. Simplified geological map of NW Iberia and its continental platform. Location of deep seismic reflection profile ESCIN-2 and the rest of the geophysical data mentioned in the text.

tava, 1989). The tectonic setting changed to NW-SE compression as a result of the convergence between plates in Cenozoic time after the change to the north in the motion of the African plate. The new compressional setting resulted in (i) the building of the Pyrenees further to the east as a result of a continental collision, (ii) the partial closure of the Bay of Biscay, (iii) the tectonic inversion of the North Iberian Margin that evolved to an active margin during the Cenozoic, and (iv) the uplift of the Cantabrian Mountains. Although the structure observed in the studied area is mainly Variscan, some Alpine structures are superposed. These later structures include (i) favourably oriented reworked Variscan thrusts and Mesozoic normal faults and (ii) newly formed faults (Alonso et al., 1996; Espina et al., 1996; Pulgar et al., 1999). Evidences of the Alpine deformation are also present further to the north in the North Iberian continental platform and abyssal plain, where north-verging thrusts developed, previous extensional Mesozoic faults were inverted, and the sedimentary cover was folded (Álvarez-Marrón et al., 1997; Gallastegui, 2000; Gallastegui et al., 2002; Fernández-Viejo et al., 2011, 2012). The present relief of the area is Alpine and its erosion supplied the detritus that filled the main synorogenic basins that developed in its boundaries: the inland Duero foreland basin in the south and the offshore Iberian Platform and abyssal plain basins in the north.
The ESCIN and MARCONI programs and other related projects were planned to study the deep crustal structure and evolution of the Cantabrian Mountains and continental margin from deep seismic reflection and refraction/wideangle data (Pérez-Estaún et al., 1994; Pulgar et al., 1995, 1996; Álvarez-Marrón et al., 1996, 1997; Gallastegui et al., 1997; Ayarza et al., 1998; Fernández-Viejo et al., 1998, 2000; Gallastegui, 2000; Gallastegui et al., 2002; Fernández-Viejo and Gallastegui, 2005; Fernández-Viejo et al., 2011, 2012). These studies showed that the deformation of the area due to the Alpine compression affected not only the shallow crustal levels but also the deeper ones. An important Alpine age crustal root developed under the uplifted Cantabrian Mountains and has been imaged in deep seismic reflection profile ESCIN-2 (Pulgar et al., 1995) and in several refraction/wideangle experiments (Pulgar et al., 1996; Fernández-Viejo et al., 1998, 2000). This thickening of the crust has also been interpreted in magnetotelluric profiles (Pous et al., 2001) and explored using teleseismic receiver function analysis of $P$ to $S$ conversions at main crustal interfaces (Díaz et al., 2003, 2009). Pedreira et al. $(2003,2007)$ and Díaz et al. (2012) proved that this structure extends eastwards beneath the Basque-Cantabrian basin and in fact it is the continuation of the same crustal root interpreted beneath the Pyrenees from other seismic experiments (ECORS Pyrenees Team, 1988; Bois et al., 1990; Muñoz, 1992; Teixell, 1998). 


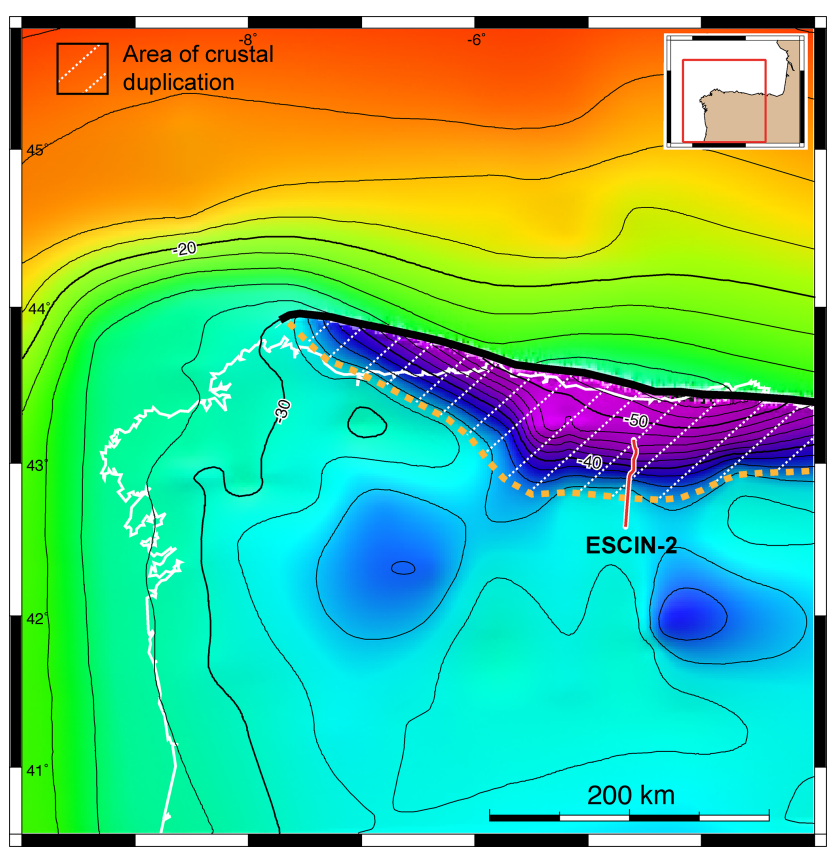

Figure 2. Interpolated crustal depth model for the NW of the Iberian Peninsula from Gallastegui (2000). The dashed area shows the extent of the area of crustal indentation. Moho depth contours are represented every $2 \mathrm{~km}$.

From a geological point of view, both areas are parts of the same Alpine belt. Crustal depth models (Fig. 2) compiled from deep sounding experiments by Gallastegui (2000) and by Díaz and Gallart (2009) also show (i) the crustal thickening, with Moho depths up to $50 \mathrm{~km}$ in the NW of the Iberian Peninsula and (ii) the continuity of this E-W crustal structure from the Pyrenees to the Cantabrian Mountains. This paper focuses on the N-S deep crustal structure of the southern part of the Cantabrian Mountains and the transition to the adjacent Cenozoic Duero basin imaged in deep seismic reflection profile ESCIN-2. A geological cross section of the area has been constructed, integrating published data (ESCIN-2, a refraction profile and a conductivity model) with a depth model of ESCIN-2 obtained by 2-D seismic modelling, a gravity model coincident with ESCIN-2, and all geological/geophysical data available (wide-angle/refraction and magnetotelluric (MT) data).

\section{Geology along ESCIN-2 deep seismic reflection profile}

Deep seismic reflection profile ESCIN-2 runs across two geological domains with dissimilar lithologies and structure, which differ in the age of the materials that crop out and their degree of deformation. The northern half of the seismic line traverses the deformed Paleozoic rocks of the Cantabrian Mountains. In the southern half these Paleozoic rocks constitute the basement of the mainly undeformed subhorizontal
Cenozoic materials that fill the Duero basin. An outcrop of almost vertical to overturned Upper Cretaceous and Cenozoic rocks separates both areas (Fig. 3).

In the northern domain the structure is mainly Variscan with minor Alpine structures superposed. The Variscan deformation affected a kilometric-thick pile of clastic and carbonate rocks that range from Silurian to Carboniferous. The line runs across a strike of Carboniferous thrusts and related folds emplaced approximately northwards. These structures are part of a thin-skinned foreland thrust and fold belt, the so-called Cantabrian Zone (Julivert, 1971; Pérez-Estaún et al., 1988, 1994; Alonso et al., 2009). The significance of the Mesozoic extensional deformation superposed in the area is difficult to infer due to the lack of Mesozoic outcrops. However, Alonso et al. (1996) deduced extensional faults in the area by projecting those that affect the Mesozoic rocks located to the east in the nearby Basque-Cantabrian basin. The Alpine compressional deformation in the area was mainly accommodated by the reactivation of previous structures: Variscan folds and thrusts and Mesozoic normal faults. The Ruesga-Ubierna fault (see R.U.F. in Fig. 3) is an example of a major Mesozoic normal fault, which was later inverted in Alpine times (Espina et al., 1996). The development of important Alpine structures is restricted to the southern border of the Cantabrian Mountains, where the overall Alpine structure is a wide monoclinal fold. Alonso et al. (1996) and Pulgar et al. (1999) interpreted it as a major fault-bend fold related to a large N-dipping basement-thrust ramp. This buried basement thrust (main Alpine thrust) cuts across the upper crust and is responsible for the basement-cored uplift of the Cantabrian Mountains. The frontal limb of the fold makes up the boundary between the Cantabrian Mountains and the Cenozoic Duero basin where Mesozoic-Cenozoic rocks are overturned. The progressive rotation of the limb during the Alpine deformation was recorded by a syntectonic unconformity that developed in the Cenozoic sediments along the northern margin of the Duero basin (García-Ramos et al., 1982; Alonso et al., 1996). This basin is considered the foreland basin of the uplifted Cantabrian Mountains.

The surface structure of the Duero basin in the southern domain is simpler. The overturned Mesozoic rocks that constitute the border of the basin progressively become horizontal towards the south and make the base of the Cenozoic basin. The Upper Cretaceous sequence is made of continental sandstones in the base (average thickness of $350 \mathrm{~m}$ ) and limestones on top ( $0-600 \mathrm{~m}$ thick). The Cenozoic sequence is an up to $3500 \mathrm{~m}$ thick pile of sandstones and conglomerates deposited by alluvial fans. These fans developed at the foot of the southern slope of the Cantabrian Mountains during the Alpine deformation and only the uppermost $100 \mathrm{~m}$ outcrop. The youngest part of the succession is horizontal, postdates the Alpine deformation, and buries in many areas the trace of the frontal Alpine thrust.

The precise age of the Alpine deformation is difficult to establish, owing to the lack of good chronostratigraphical 


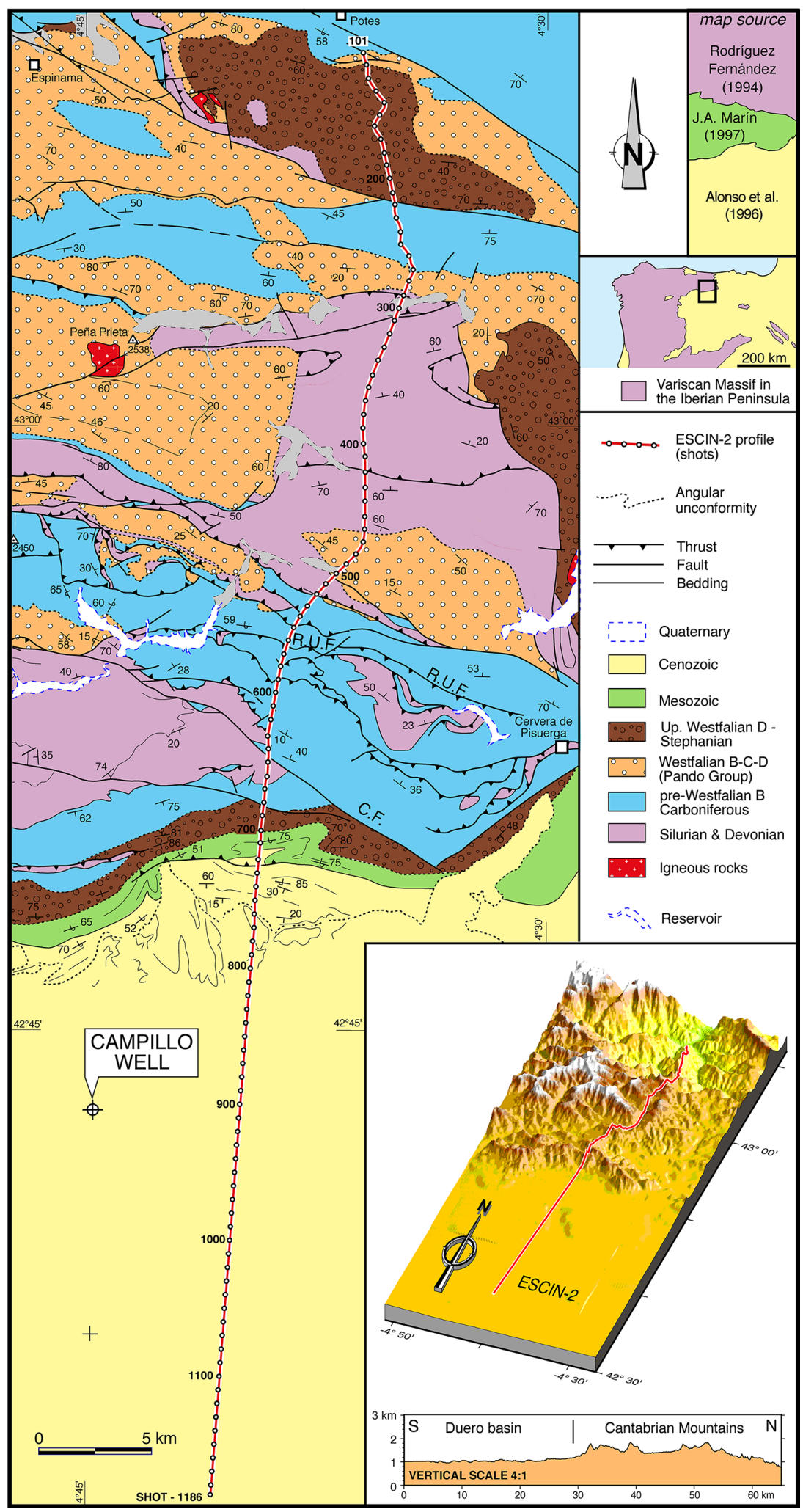

Figure 3. Geological map of the studied area. The inset box in the lower right-hand corner shows a 3-D DTM view of the region and the elevations profile along ESCIN-2 that shows the flat topography in the Duero basin in contrast with the rugged mountainous terrain in the Cantabrian Mountains. Geological map compiled from Rodríguez-Fernández (1994), Alonso et al. (1996) and Marín (1997). 


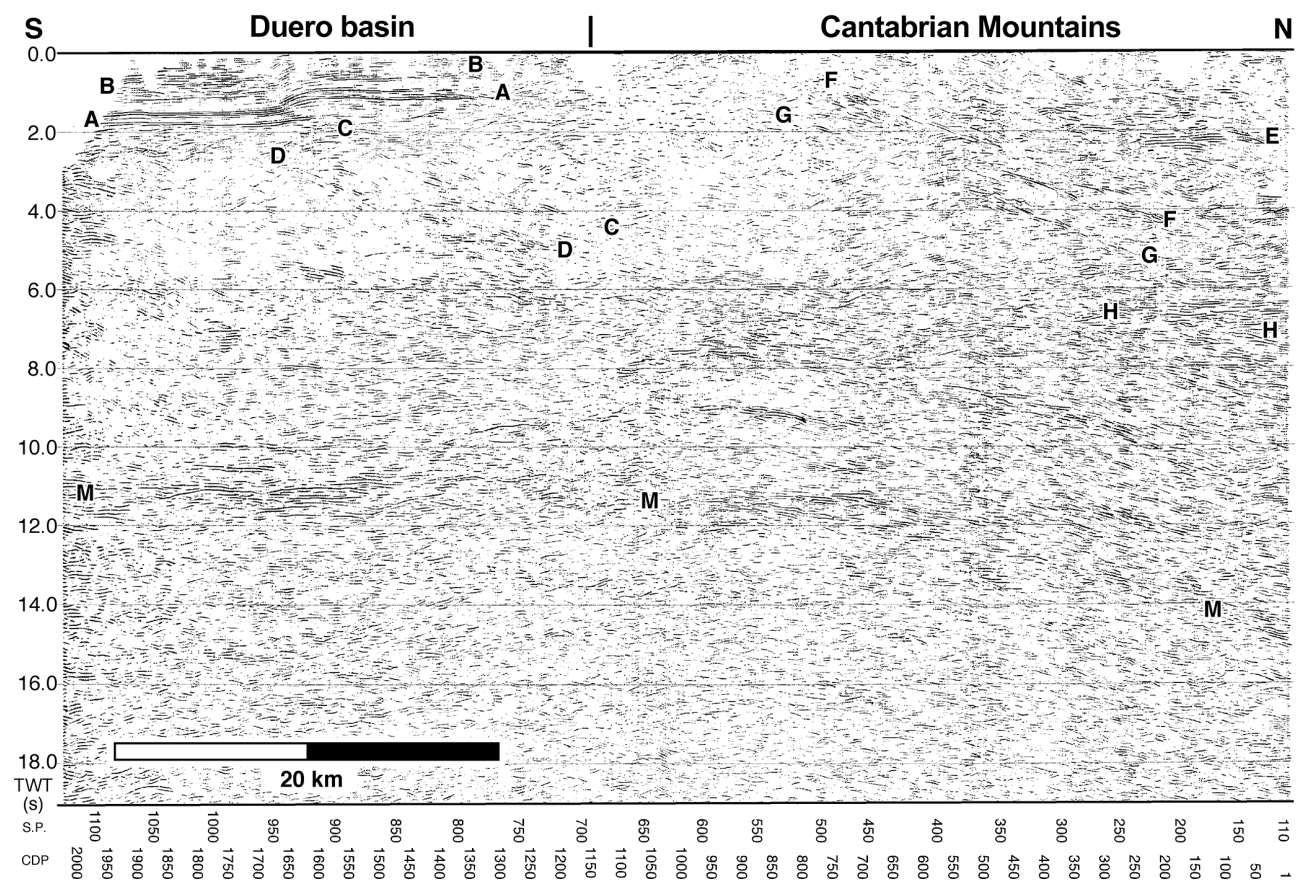

Figure 4. Coherency filtered stack section of ESCIN-2 with the interpretation of the main reflectors and crustal levels described in the text.

data in the mainly detritic and azoic Cenozoic sequence. However, the age of the deformation can be estimated between the Oligocene to upper Miocene from Ostracoda fauna found near the base of the Cenozoic basin (López Olmedo et al., 1997) and mammal remains from the top of the Cenozoic succession further to the east (Portero García et al., 1982). This time span coincides with the ages of uplift of the Cantabrian Mountains recorded by apatite fission tracks to the west (Martín-González et al., 2011).

\section{ESCIN-2 profile: description, interpretation and seismic modelling}

The $65 \mathrm{~km}$ long deep seismic reflection profile ESCIN-2 was designed to investigate the $\mathrm{N}-\mathrm{S}$ crustal structure of the southern tectonic front of the Cantabrian Mountains and the transition to the Cenozoic Duero foreland basin (Fig. 3). The northern segment of the line crossed rugged topography with altitudes between 770 and $1850 \mathrm{~m}$ above sea level (a.s.l.), whilst the topography in the south is almost flat around $1000 \mathrm{~m}$ a.s.l. (datum plane $1000 \mathrm{~m}$ ). The line was acquired with a 240 channel geophone spread, using $60 \mathrm{~m}$ geophone group spacing and laid out as a symmetrical split spread with roll-on. A total of 212 single-hole dynamite shots $(10-25 \mathrm{~kg})$ were recorded. The record length was $25 \mathrm{~s}$ with a mean value of 30 for the fold coverage. More detailed information on data acquisition and processing parameters of the stack section is in Pulgar et al. $(1995,1996)$. The section was processed following a standard sequence and post-stack lateral coherency filtering was applied later (Fig. 4). The geological interpretation of the shallow reflections in the Duero basin is also constrained by a set of 38 oil exploration seismic reflection profiles (Fig. 1) that provide a clearer seismic image of the shallow levels, particularly in the transition to the Cantabrian Mountains (Gallastegui, 2000). Three oil exploration wells provided the lithological calibration of the seismic data allowing the identification of reflectors in the seismic sections (Fig. 1). The Campillo well is located only $6.5 \mathrm{~km}$ to the west of ESCIN-2 and $1895 \mathrm{~m}$ of Cenozoic and $660 \mathrm{~m}$ of Mesozoic were drilled before reaching the Paleozoic basement (Ordovician or Silurian).

\subsection{Data description and geological interpretation}

The quality of the crustal seismic image is good along the profile, although reflectivity is weaker, especially in the upper $4 \mathrm{~s}$, in the transition between the Duero Basin and the Cantabrian Mountains (Fig. 4). This can be attributed to bad shot quality in this area, where important lithological lateral variations and residual statics problems are evidenced by the delay in the first arrivals in the shot gathers. (See the southern part of shot 560 in Fig. 5b.)

The southern half of the profile is characterized by horizontal reflectors at all crustal levels (up to $12 \mathrm{~s}$ ) beneath the Duero basin. Reflectors are very continuous (up to tens of $\mathrm{km}$ ) and well defined in the upper $2 \mathrm{~s}$. Amplitudes are especially high in a lower horizontal band at $1.5-2 \mathrm{~s}$ (A in Figs. 4, 5a, and 6a) that corresponds to the Upper Cretaceous rocks in the base of the sedimentary Duero basin. Reflections 


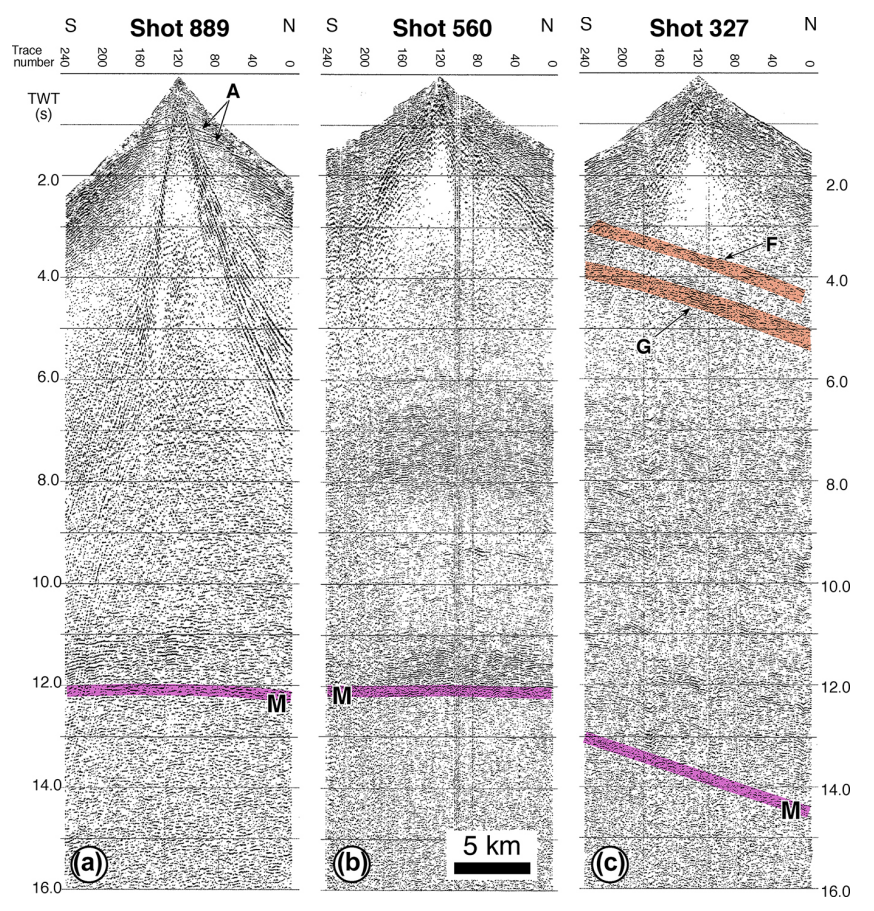

Figure 5. Three shot gathers from ESCIN-2 deep seismic reflection profile. (a) Shot gather from the Duero basin (A reflections from the Cretaceous levels that drape the bottom of the basin). (b) Shot gather from the transition to the Cantabrian Mountains; note the increase in reflectivity below $6 \mathrm{~s}$ and the base of horizontal Moho (M) at 12 s. (c) Shot gather from the Cantabrian Mountains. Northdipping reflecting bands are more conspicuous than in the stack section ( $\mathrm{F}$ and $\mathrm{G})$. Moho is dipping to the north and reaches a maximum depth of almost $15 \mathrm{~s}$.

from the overlying Cenozoic (B) are also horizontal but less continuous and with less amplitude. Both levels (A and B) are curved and slightly shifted upwards (about $0.5 \mathrm{~s}$ ) to the north of the basin. The upper crust beneath the basin, up to a depth of $5.5 \mathrm{~s}$, is almost transparent aside from two thin bands of discontinuous and aligned $\mathrm{N}$-dipping reflectors that can be traced from the base of the basin to the base of the upper crust at $5.5 \mathrm{~s}$ where they sole (C and D in Figs. 4 and 6a). The former feature (C) cuts the Upper Cretaceous and base of the Cenozoic reflectors, in coincidence with the area where they are vertically shifted, and the latter (D) is less conspicuous and fades below the sedimentary basin. Reflectivity increases abruptly below $5.5 \mathrm{~s}$ in the reflective middle and lower crust up to a depth of $12 \mathrm{~s}$. The reflection Moho is continuous and consistent below the Duero basin and the transition to the Cantabrian Mountains. Moho reflections are prominent and make up a $1 \mathrm{~s}$ thick band of subhorizontal and slightly anastomosed reflectors at 10-12 s (M in Figs. 4, 5a and $b$, and $6 \mathrm{~d}$ ) above a less-reflective upper mantle.

The seismic pattern across the crust is quite different in the northern part of the profile below the Cantabrian Mountains, since all the crust is reflective and Moho depth and crustal thickness gradually increase northwards. The upper crust is reflective and dominated by near-horizontal reflections, which are particularly energetic at $2 \mathrm{~s}$ in the northern end of the profile (E in Fig. 4). Two parallel bands of Ndipping discontinuous reflectors, similar to those described below the Duero basin, cut the upper crust and almost reach the surface (F and $\mathrm{G})$ (Figs. 4 and $6 \mathrm{~b}$ ). The same N-dipping events are even more conspicuous in some of the shot gathers (for example, see shot 327 in Fig. 5c). Moreover, exploration profiles, such as $\mathrm{N} 03$ in Fig. 7, provide a clearer image of the nature of these structures near the surface. The N-dipping bands, interpreted in ESCIN-2 and N03, are correlated in the surface with major Variscan and Mesozoic fractures that reworked during the Alpine inversion. The horizontal middle and lower crustal reflectors observed below the Duero basin extend northwards but gradually bend to the north and are clearly dipping northwards underneath the Cantabrian Mountains. Horizontal Moho reflections at $12 \mathrm{~s}$ below the Duero basin also deepen to the north and reach a maximum depth of $15 \mathrm{~s}$ in the northernmost end of the profile (M in Figs. 4, $5 \mathrm{c}$, and $6 \mathrm{~d}$ ). In this area, a wedge-shaped area of subhorizontal reflectors between 6 and $9 \mathrm{~s}(\mathrm{H})$ is truncated against the top of the N-dipping package of reflectors (Figs. 4 and $6 \mathrm{c}$ ). The mantle shows no prominent features and only short and discontinuous reflections can be traced parallel to the Moho topography (Fig. 4).

\subsection{Seismic modelling results}

Two-dimensional forward seismic modelling produces a geological model by comparing its seismic response with the real seismic data. In this case, forward seismic modelling of deep seismic reflection profile ESCIN-2 (Fig. 8) was used to (i) check the theoretical ray coverage of the seismic profile, (ii) support the proposed geological interpretation, and (iii) obtain the depth of the different interfaces interpreted. (Further explanation of the process in Gallastegui et al., 1997.)

The first modelling step was to construct a geological model of the crust, following the direction of the profile. The main reflectors and crustal levels interpreted in the seismic section and all geological and geophysical data available were included. One of the key points of the modelling technique is to precisely establish the detailed P-wave velocitydepth distribution of the model (Fig. 9b). Velocities in the model were determined from three main sources: (i) the velocities of the materials that fill the Duero basin were deduced from the three exploration wells available in the area. An interval velocity of 3.7 and $4.8 \mathrm{~km} \mathrm{~s}^{-1}$ was calculated for the Cenozoic and Cretaceous sequences from their respective thicknesses in the wells and the equivalent two-way travel time in exploration profiles. (ii) The velocities of the materials that outcrop in the Cantabrian Mountains are consistent with measurements of similar Variscan rocks in nearby locations (Gutiérrez-Claverol et al., 1994). (iii) The rest of the 

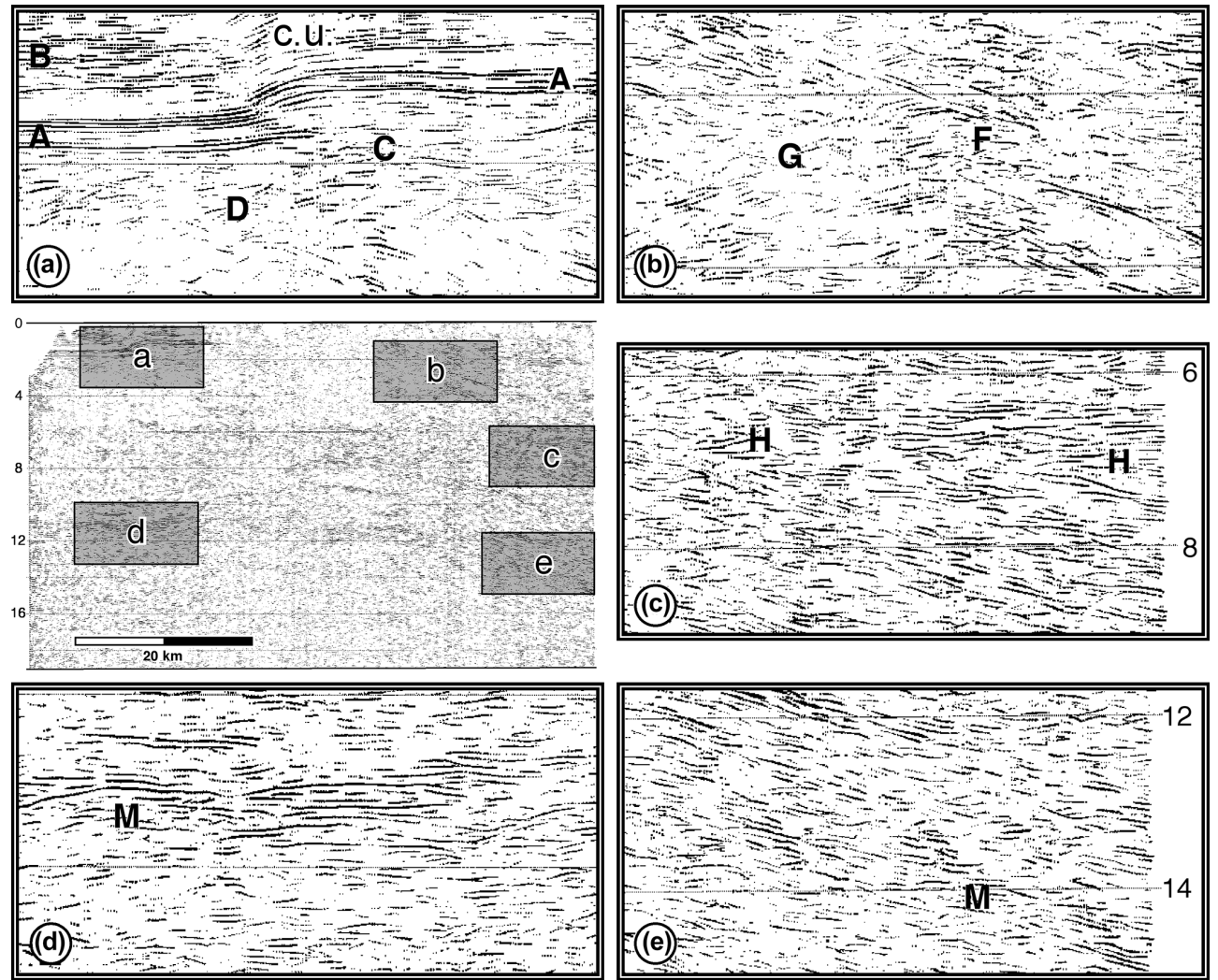

Figure 6. Magnification windows from selected regions of ESCIN-2. (a) Campillo thrust (C) and Campillo uplift (c.u.) in the Duero basin. (b) North-dipping band of reflectors interpreted as crustal scale thrusts ( $F$ and $G$ ). (c) Wedge of subhorizontal reflectors indented in the crust (H). (d) Horizontal reflection Moho (M) at the base of the crust (11 s) beneath the Duero basin. (e) North-dipping reflection Moho at the base of the crust reaching a depth of $15 \mathrm{~s}$ below the Cantabrian Mountains.

velocities were directly taken from a $200 \mathrm{~km}$ long $\mathrm{N}-\mathrm{S}$ refraction profile (described in the next section), which is coincident in the central part with ESCIN-2 (Fig. 9a) (Pulgar et al., 1996). Despite the limited resolution of refraction profiles, the refraction velocity values were used as they are the only data available in this area.

A synthetic seismogram of the profile (Fig. 8b) was generated by 2-D normal incidence ray tracing in the velocitydepth model (Fig. 8a) in the next modelling step. The synthetic profile depicts the theoretical seismic response of the model. It is composed of 184 synthetic traces in a relation of 1 synthetic trace for every 11 real traces in ESCIN-2. Finally, the synthetic seismogram profile was compared with the real seismic data and the initial model was gradually changed until a satisfactory fit was achieved between the real and synthetic seismic data (Fig. 8c). The ray-path plot in the model (Fig. 8a) showed the good theoretical normal-incidence ray coverage of the different levels interpreted in the profile, giving thus a good confidence level to the interpretation. Only the lowest crustal levels in the northern end of the profile are not sampled due to their N-dipping attitude.

The crustal thickness of the final model is close to $33 \mathrm{~km}$ in the south under the Duero basin, where the crust can be divided in three subhorizontal levels: the upper crust, up to a depth of almost $14 \mathrm{~km}$, and the middle and lower crust (Fig. 9b). The depth of the boundary between the middle and lower crust was directly taken from the refraction profile described in next section and it was included in the model in order to check the compatibility between refraction and reflection data. Crustal thickness increases to more than $47 \mathrm{~km}$ in the northern end of the profile under the Cantabrian Mountains. The boundary between the upper and middle crust also deepens northwards and reaches a depth of $26 \mathrm{~km}$. One of the most interesting results is that the inclined bands of reflections in the upper crust below the Duero basin and the Cantabrian Mountains dip to the north (30.5-36 $)$ and reach a depth of $14 \mathrm{~km}$ in the boundary between the upper and middle crust.

\section{Other geophysical data}

\subsection{Seismic refraction profile}

A $200 \mathrm{~km}$ long N-S reversed refraction profile was recorded inland to complement the seismic reflection data. This profile extends from the North Iberian coastline in the north to 


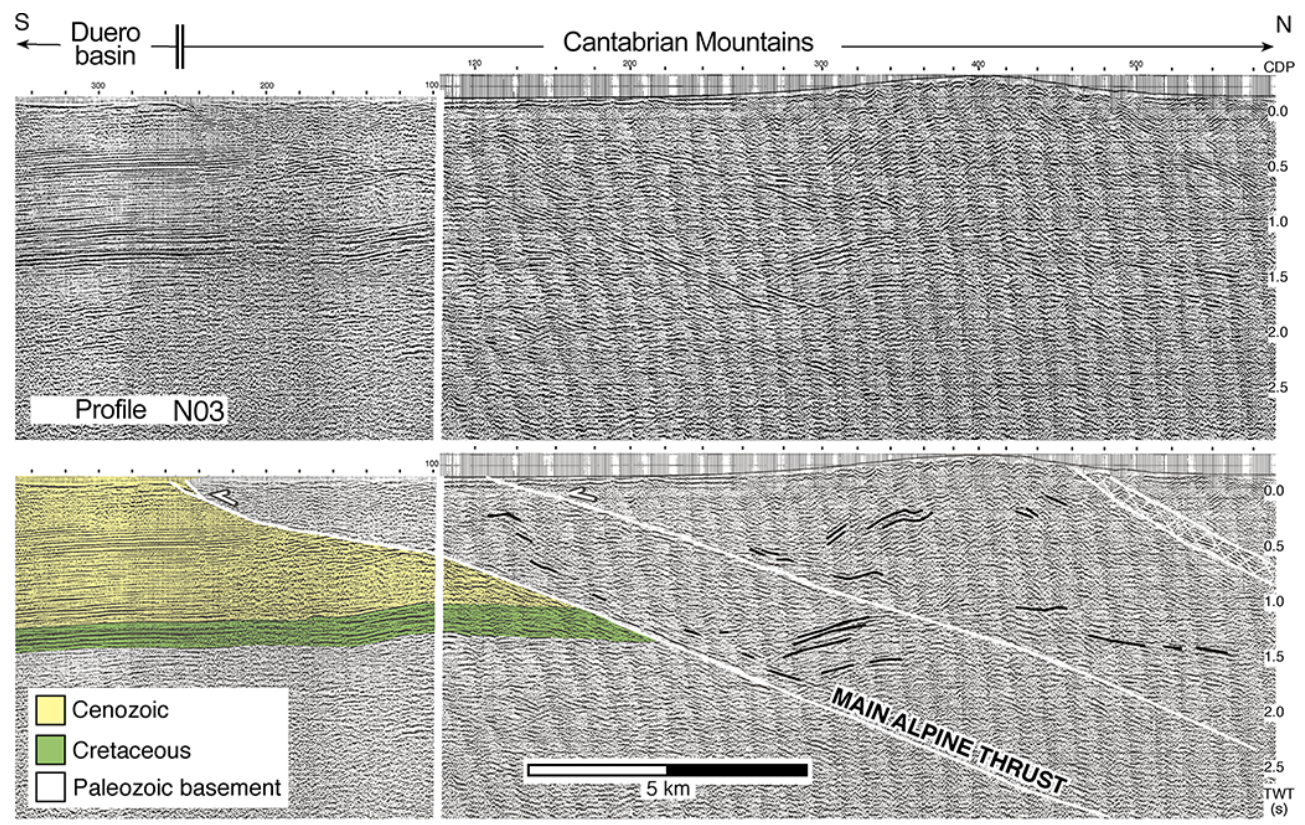

Figure 7. Commercial seismic reflection profile N03 across the northern border of the Duero basin (location in Fig. 1). Note the N-dipping reflectors that can be correlated with reflective bands F and G in ESCIN-2. The southernmost one corresponds to the main alpine thrust in the border of the basin and the northern one coincides in the surface with a major Variscan structure reworked in Alpine times.

the centre of the Duero basin in the south. It was designed to traverse the Cantabrian Mountains and is parallel to ESCIN2 (Fig. 1). The profile provided the first seismic crustal image across the Cantabrian Mountains (Fig. 9a) (Gallart et al., 1995; Pulgar et al., 1996; Fernández-Viejo, 1997; FernándezViejo et al., 2000). The most outstanding feature of the profile is the $\mathrm{S}-\mathrm{N}$ crustal structural variation. The velocitydepth distribution and structure under the Duero basin are characteristic of the Variscan crust found in previous profiles along the North Iberian Variscan Massif (Córdoba et al., 1988). However, crustal thickness increases northwards gradually and an Alpine crustal root is well developed under the Cantabrian Mountains. Moho depth is well constrained from $32 \mathrm{~km}$ in the south to $45 \mathrm{~km}$ at about $30 \mathrm{~km}$ inland beneath the Cantabrian Mountains. This crustal thickening has also been imaged in other $\mathrm{N}-\mathrm{S}$ wide-angle experiment located about $50 \mathrm{~km}$ to the west that extends northwards in the Cantabrian Margin (Pulgar et al., 1996; Fernández-Viejo, 1997; Fernández-Viejo et al., 1998). Nearby E-W refraction profiles show that the crustal root trends $\mathrm{E}-\mathrm{W}$ and disappears westwards in the continental margin (Fernández-Viejo, 1997; Fernández-Viejo et al., 2000) and extends eastwards under the Basque-Cantabrian basin in continuity with the Pyrenean crustal root (Pedreira et al., 2003, 2007).

\subsection{Gravity profile}

To further constrain the interpretation of the seismic data a 2-D gravity profile was modelled (Fig. 9d-e). A Bouguer anomaly map was compiled (Gallastegui, 2000) with data supplied by the BGI (Bureau Gravimétrique International) and complemented with new measurements collected for this research (Fig. 10). Data are referenced to the IGSN-71, converted to free-air anomalies using the Geodetic Reference System Formula (GRS-67) and to simple Bouguer anomalies with a density of $2670 \mathrm{~kg} \mathrm{~m}^{-3}$. Terrain corrections were computed to a distance of $20 \mathrm{~km}$ around each measured point. The Bouguer anomaly shows an E-W elongated gravity low located to the west of the southern end of ESCIN-2 that reaches values around $-90 \mathrm{mGal}$ and extends to the end of ESCIN-2, where the anomaly has a value of $-75 \mathrm{mGal}$. The anomaly low superposes the area with the thickest sedimentary fill in the northern part of the Duero basin. Bouguer anomaly values gradually increase northwards towards the coastline, where anomaly values range from 0 to $30 \mathrm{mGal}$.

Depths of the interfaces to construct the model were directly taken from seismic data and densities of the crustal levels were calculated from P-wave velocities obtained from the refraction profile parallel to ESCIN-2. The chosen densities were $2670-2700 \mathrm{~kg} \mathrm{~m}^{-3}$ for the upper crust, $2750 \mathrm{~kg} \mathrm{~m}^{-3}$ for the middle crust, $2850-2900 \mathrm{~kg} \mathrm{~m}^{-3}$ for the lower crust, and $3300 \mathrm{~kg} \mathrm{~m}^{-3}$ for the upper part of the mantle. The densities of the Mesozoic rocks in the Duero basin $\left(2620 \mathrm{~kg} \mathrm{~m}^{-3}\right)$ were converted from the velocities defined previously from well data and the densities of the Cenozoic levels decrease southwards from 2600 to $2250 \mathrm{~kg} \mathrm{~m}^{-3}$ because of the change to distal and finer-grained facies in that direction.

Two-dimensional gravity modelling of the data shows that the density model and the structure deduced from geolog- 


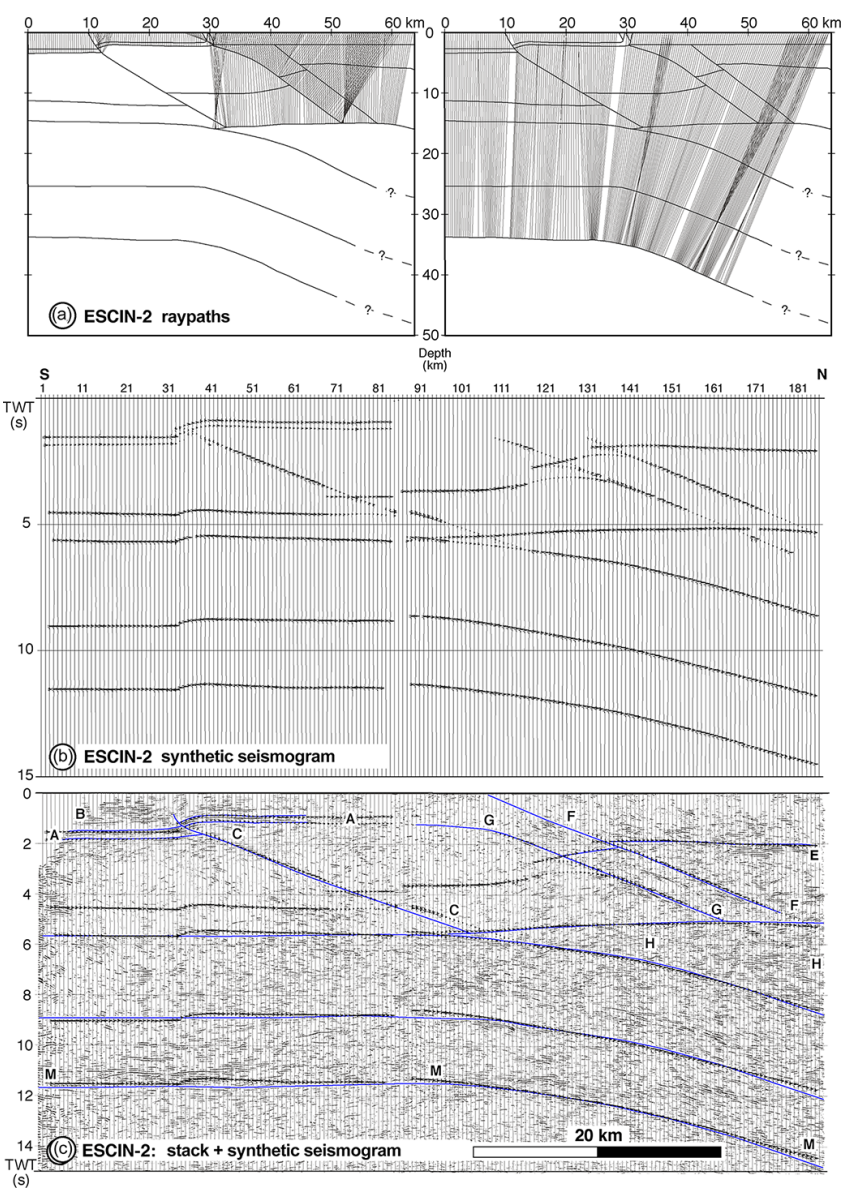

Figure 8. (a) Ray-path plot of normal incidence ray tracing to different interfaces in the final ESCIN-2 velocity depth model in Fig. 9b. Note the areas with no theoretical ray coverage under the Cantabrian Mountains. (b) Synthetic seismogram obtained from normal incidence ray tracing showing the seismic response of the same velocity-depth model. (c) Synthetic seismogram of the final model superimposed on ESCIN-2 and the boundaries of the velocity-depth model. It shows a good match between the real and synthetic seismic data.

ical and seismic data can account for the observed gravity anomalies. Moho depths are in agreement with those derived from other geophysical methods, increasing from $32 \mathrm{~km}$ under the Duero basin to almost $50 \mathrm{~km}$ under the Cantabrian Mountains. The gravity low in the south is related to the sedimentary fill of the Duero basin and anomaly values increase northwards due to the combined effect of (i) the superposition of the northern lower and middle crust above the crustal root and (ii) the thinning of the crust towards the North Iberian continental margin. This thinning is not shown in Fig. 9d since it occurs further to the north, but its gravity effect is included in the profile (Fig. 9e). Both effects contribute to mask the expected anomaly low that the crustal root would produce.

\subsection{Magnetotelluric profile}

Pous et al. (2001) built a 2-D conductivity model, almost coincident with ESCIN-2, from the coastline to the Duero basin. The interpreted structures in the seismic section fit with those in the magnetotelluric model (Fig. 9f). In the upper crust several $\mathrm{N}$-dipping high electrical conductivity zones reach a depth of $15 \mathrm{~km}$. The southernmost one is coincident with dipping reflections $\mathrm{F}$ and $\mathrm{G}$ interpreted in ESCIN2. Further north, between the northern end of the seismic profile and the coastline, other $\mathrm{N}$-dipping conductors image at depth the prolongation of two major outcropping Alpine faults (Cabuerniga and San Vicente de la Barquera faults) parallel to the structures shown in the reflection profile. Both models also coincidence at deeper crustal levels. First, a wedge-shaped conductive zone is in the same position as the wedge of reflectors named $\mathrm{H}$; second, the MT model has also shown the crustal thickening under the Cantabrian Mountains, which was revealed by the rest of the geophysical data.

\section{Geological interpretation and discussion}

One of the distinctive seismic features of the studied area is the change in the reflectivity pattern and the crustal structure between the southern and northern part (Figs. 4b and 11). The southern part (below the Duero basin) is characterized by poor reflectivity in the almost transparent upper crust (down to 5-6 s or $14 \mathrm{~km}$ depth) and an abrupt increase in reflectivity below. The high reflectivity is persistent in the reflective lower crust up to a depth of 10-12 s (approximately $32 \mathrm{~km}$ ), ending in a sharp contrast between a conspicuous reflective Moho and a less reflective upper mantle. However, the whole crust is reflective in the northern domain (below the Cantabrian Mountains) and the crust is thickened to $15 \mathrm{~s}$ (about $45 \mathrm{~km}$ ) as a result of an important Alpine reworking of the crust at all crustal levels.

The interpretations of the commercial seismic reflection profiles and ESCIN-2 show that the Duero basin was only slightly deformed in the Alpine deformation event (Fig. 11). The only structures that evidence the compressional deformation are found (i) in the northern border where the Mesozoic and base of the Cenozoic are overturned and a syntectonic unconformity developed in the upper part of the Cenozoic succession (Alonso et al., 1996) and (ii) $14 \mathrm{~km}$ to the south of the mountain front where a buried progressive unconformity and a minor uplift (Campillo uplift) and drape fold developed in the Mesozoic and Cenozoic succession (Figs. 4 and 6a). The two parallel band of reflectors located below the Duero basin (bands C and D in ESCIN-2) are interpreted as basement thrust that seem to sole in the transition between the upper and middle crust at $14 \mathrm{~km}$. Band C corresponds to the buried Campillo thrust responsible for the deformation of the Cenozoic rocks and the Campillo uplift in its hanging wall, which are imaged in ESCIN-2 and other com- 


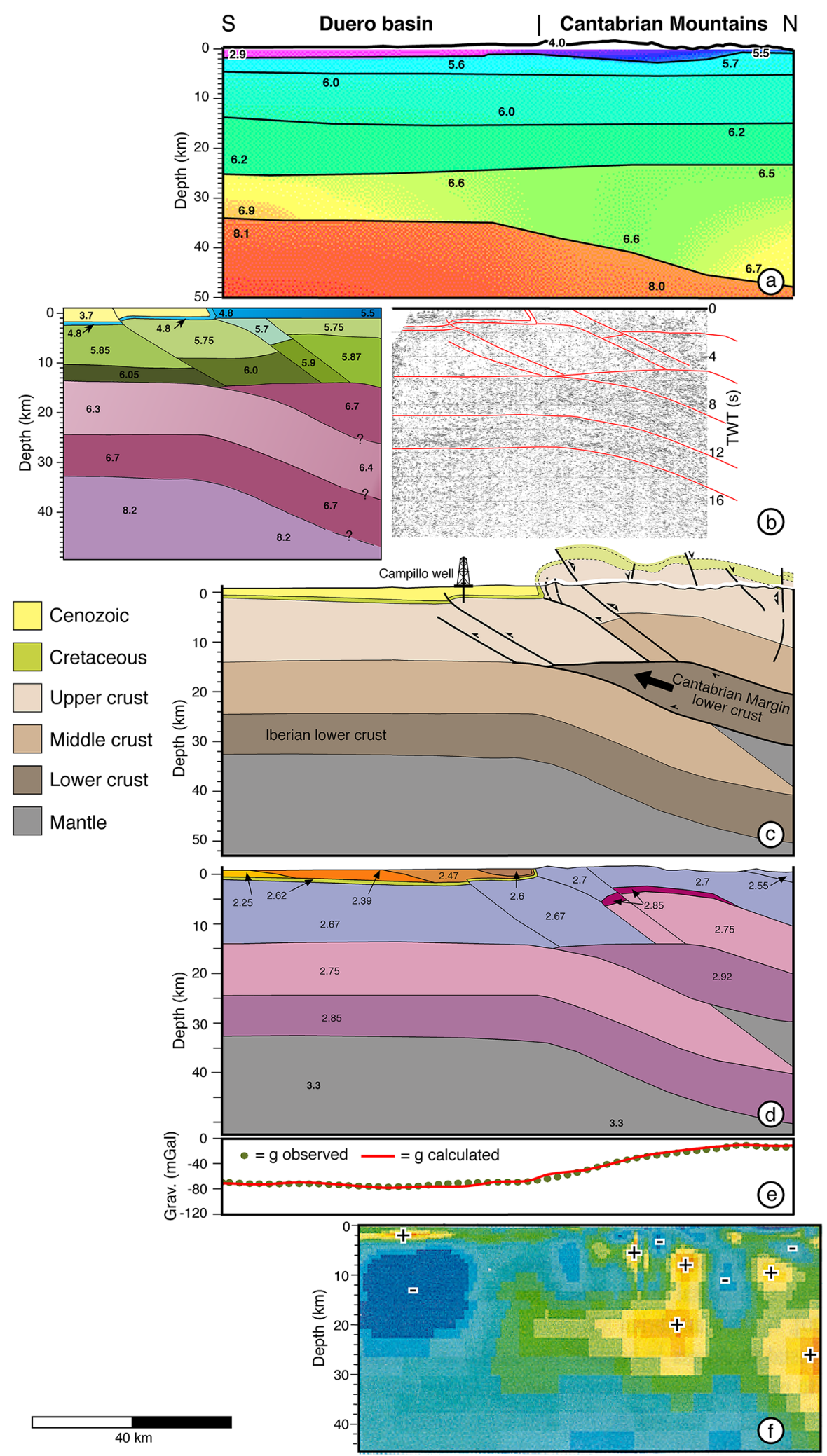

Figure 9. (a) Refraction velocity model parallel to ESCIN-2 (Pulgar et al., 1996; Fernández-Viejo, 1997; Gallart et al., 1995). (b) Velocitydepth model of ESCIN-2 obtained by forward seismic modelling of interphases shown in red in the interpreted deep seismic section. (c) Geological cross section of the area that synthesizes all information available. (d, e) Two-dimensional gravity model, observed and calculated gravity anomaly of the studied area (Gallastegui, 2000). (f) Two-dimensional electrical resistivity model and location of resistivity highs and lows (adapted from Pous et al., 2001). 


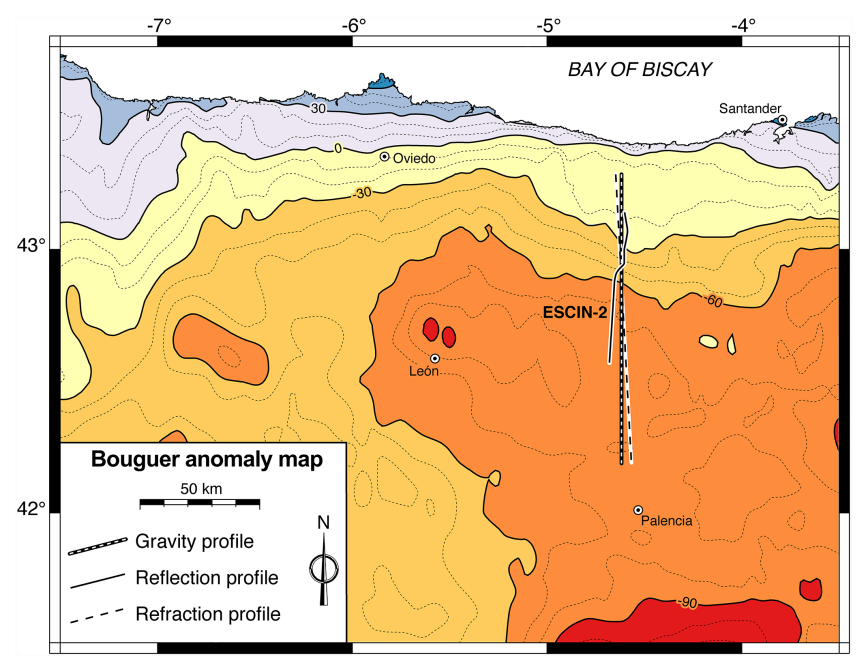

Figure 10. Bouguer anomaly map compiled with data supplied by the BGI (Bureau Gravimétrique International) and complemented with new measurements collected for this study.

mercial seismic reflection profiles. Band D is a secondary parallel thrust, which fades out upwards and did not displace the base of the basin.

The Alpine deformation was more intense below the Cantabrian Mountains. The N-dipping bands of reflectors that cut across the upper crust in ESCIN-2 are the seismic expression of the compressional structures responsible for this deformation. These basement faults have also been interpreted by the magnetotelluric method (Pous et al., 2001). Band $\mathrm{G}$ is the seismic image of the main Alpine thrust, previously interpreted by Alonso et al. (1996) from geological data. According to these authors, the southward displacement along this basement-involved thrust produced the uplift of the Cantabrian Mountains and the overturning of the northern border of the Duero basin. Parallel band F matches in surface with the Mesozoic extensional Ruesga-Ubierna Fault (Fig. 3) that also reworked as a thrust in Alpine times. Both thrusts cut across the upper crust up to a depth of $14 \mathrm{~km}$, where they seem to sole in the boundary with the middle crust. This is also the depth of the base of the seismic zone in the area (Llana-Fúnez and López-Fernández, 2015). The main Alpine thrust shows no associated prominent reflections in the upper $2 \mathrm{~s}$ in ESCIN-2; however, this upper part has been clearly imaged in the commercial reflection profiles, together with other $\mathrm{N}$-dipping thrusts located further to the north that coincide in the surface with Variscan structures that reworked during the Alpine event. (Profile N03 in Fig. 7). The dip of the crustal thrust deduced from reflection data is $30-36^{\circ}$, which is significantly different than the one interpreted for the main Alpine thrust from geological data $\left(16^{\circ}\right)$. The same steep angle was found in a similar crustal-scale thrust interpreted in COCORP Wind River profile (Wyoming) (Smithson et al., 1979).
One of the most striking features in the profile is the crustal thickening beneath the Cantabrian Mountains revealed by the deepening of the Moho from $33 \mathrm{~km}(12 \mathrm{~s})$ in the south to $47 \mathrm{~km}(15 \mathrm{~s})$ in the north. The maximum Moho depth has been established at $55 \mathrm{~km}$ below the coastline by refraction/wide-angle modelling. The deepening is progressive as a consequence of the simultaneous bending of the middle and lower crust. The top of the middle crust gets deeper from $14 \mathrm{~km}$ below the Duero basin to about $26 \mathrm{~km}$ in the north. The wedge of reflectors $(\mathrm{H})$ plays a major role in the interpretation of the Alpine structure of the profile and has to be considered in a broader regional perspective. The lower crust of the Cantabrian margin is detached and was underthrusted to the south under the North Iberian margin due to the alpine deformation that affected the area. This lower crust deeply indented to the south into the Iberian crust, below the Cantabrian Mountains, and split the latter, whose lower portion (middle and lower crust) was forced to subduct to the north, building a crustal root. The wedge of reflectors $(\mathrm{H})$ represents the southernmost end of the Margin lower crust, which also forced thrust emplacement and the Alpine uplift of the Cantabrian Mountains. The overall crustal structure is very similar to that of other Alpine collisional orogens such as the Pyrenean range. In fact, the Pyrenees constitutes the eastern continuation of the Cantabrian Mountains and developed in the same tectonic event. In the Pyrenees the Iberian plate is also indented by a wedge of its northern counterpart plate and is forced to subduct northwards, creating a crustal root. One key difference between both mountain ranges is that the latter is a collisional orogen, whilst no collision occurred in the Cantabrian Mountains. However, the continuity between both Alpine roots indicates that the overall crustal structure of the Cantabrian Mountains may have been conditioned and driven by the onset of deformation and initial development of the Pyrenean root at the end of Cretaceous times (Teixell, 1998). The alpine deformation migrated westwards towards the studied area, where deformation occurred during the Paleocene-Eocene (Gallastegui, 2000). According to Martín-González et al. (2014), deformation developed even later (Early Oligocene) in the westernmost parts of the Cantabrian Mountains.

\section{Conclusions}

Deep seismic reflection profiling in the southern branch of the Cantabrian Mountains and the transition to the Cenozoic Duero basin has provided a good image of the crustal structure (Fig. 11). The crust exhibits $\mathrm{N}-\mathrm{S}$ lateral variations that result from the superposition of the Alpine orogenic deformation (Cenozoic) on a Variscan structured crust. The crust below the foreland Duero basin is almost undeformed and shows a reflective pattern that is common for most of the undeformed Caledonian and Variscan crusts in Europe, according to Mooney and Meissner (1992). An almost trans- 

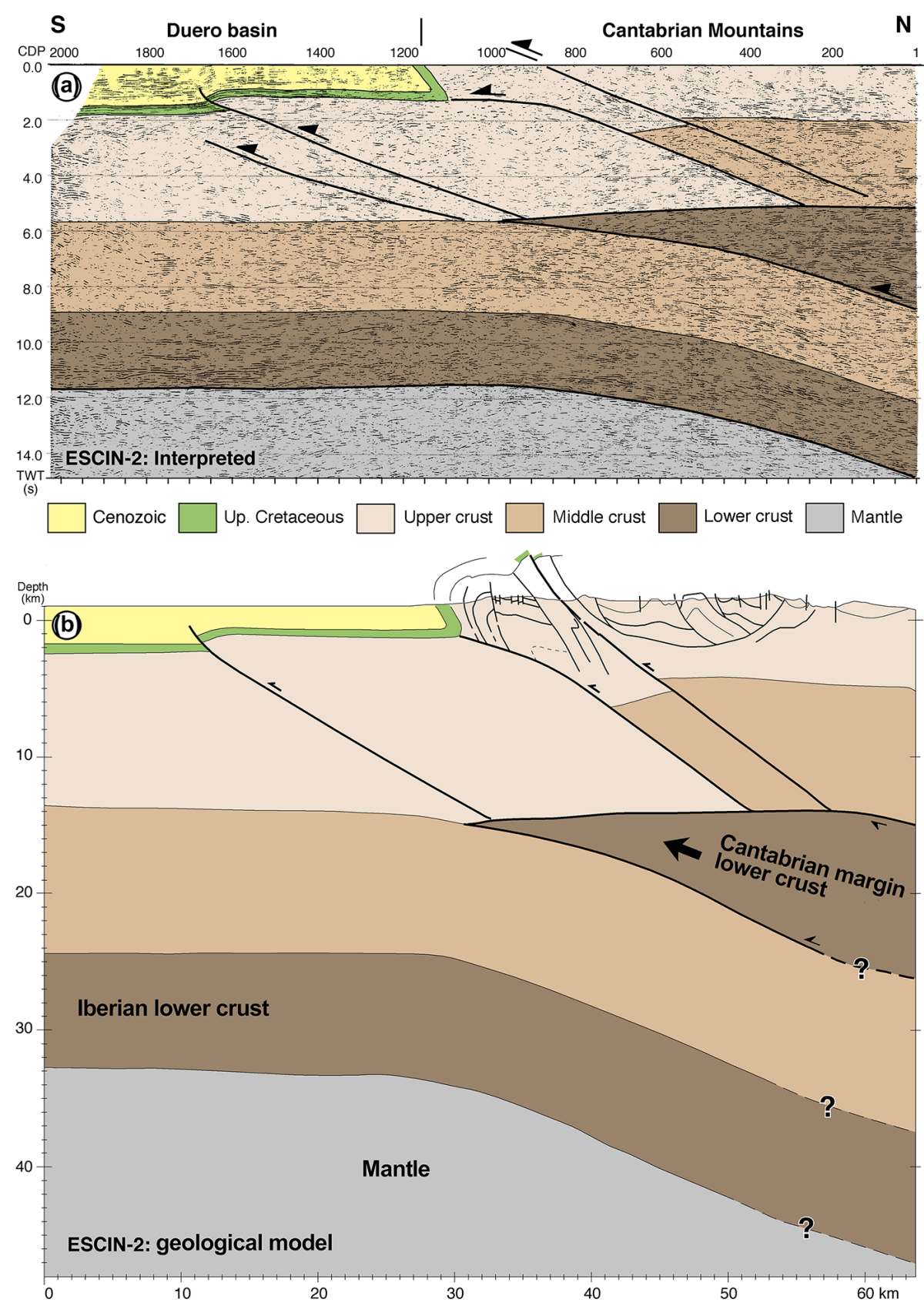

Figure 11. (a) Interpreted stack section of ESCIN-2. (b) Geological interpretation of ESCIN-2. The base of the crust deepens from almost $33 \mathrm{~km}$ below the Duero basin to $47 \mathrm{~km}$ under the Cantabrian Mountains due to the indentation of the Cantabrian Margin lower crust into the detached Iberian crust.

parent upper crust, below the slightly deformed Mesozoic and Cenozoic deposits that fill the Duero basin, overlies a reflective lower crust from 14 to $32 \mathrm{~km}$, where an energetic reflective Moho leads to a poorly reflective upper mantle. However, as a result of the Alpine orogeny, that led to the building of the Pyrenees further to the east, the crustal reflectivity pattern changes significantly below the Cantabrian Mountains. The whole crust is reflective as a result of the Alpine reworking. The main shallow structures are a set of N-dipping base- ment thrusts $\left(30-36^{\circ}\right)$ that cut the upper crust and sole at $14 \mathrm{~km}$ in a common detachment. The most important one is the Main Alpine Thrust, whose propagation fold gives shape to the northern boundary of the Duero basin and is responsible for the Alpine uplift of the Cantabrian Mountains. Other crustal thrusts interpreted in the north in ESCIN-2, and several commercial reflection profiles, coincide in surface with major Variscan and/or Mesozoic structures that reworked in Alpine times. 
Another result of the Alpine deformation, shown in seismic profiles (ESCIN-2 and refraction experiments) and confirmed by other geophysical methods (gravity and MT modelling) is that the crustal thickness gradually increases northwards below the Cantabrian Mountains, reaching a maximum of $55 \mathrm{~km}$ beneath the coastline. We have interpreted a process of tectonic wedging and duplication of the crust as a result of the southward indentation of the lower crust of the Iberian Margin, which forced the delamination and northward subduction of the Iberian crust at deep crustal levels. This process drove the emplacement of the aforementioned thrusts in the upper crust. The overall crustal structure is similar to the one found in the Pyrenees where an Alpine crustal root developed as a result of the collision between two continental plates. In fact, although the Basque-Cantabrian basin separates both mountain ranges, the Alpine crustal root is continuous between them, making them a single and continuous orogen at the crustal scale. The development of the Pyrenean root in the Upper Cretaceous and the progressive westwards migration of the Alpine deformation from the Pyrenean area to the Cantabrian Mountains conditioned the structure in the latter, where $\mathrm{N}-\mathrm{S}$ plate convergence took place but with no collision.

Acknowledgements. This study was part of the $\mathrm{PhD}$ thesis of J. Gallastegui and was supported by a FPU grant and research projects GEO 90-0660-1086 and PB92-1013 funded by CICYT (Committee of Science and Technology of the Spanish Ministry of Education and Science) and FICYT (Foundation for the Science and Technologic Research, Government of Asturias, Spain). Part of the study has also been financed by the Spanish Ministry of Science through the "TOPOIBERIA" Consolider Project (ref: MEC-06-CSD2006-0041) and the MISTERIOS Project (ref: MINECO-13-CGL2013-48601-C2). We gratefully acknowledge the Bureau Gravimétrique International (BGI) for providing part of the gravity data and REPSOL for providing commercial seismic reflection profiles.

Edited by: R. Carbonell

Reviewed by: two anonymous referees

\section{References}

Alonso, J. L., Pulgar, J. A., García-Ramos, J. C., and Barba, P.: Tertiary basins and Alpine tectonics in the Cantabrian Mountains (NW Spain), in: Tertiary basins of Spain: the stratigraphic record of crustal kinematics, edited by: Friend, P. F. and Dabrio, C. J., Cambridge University Press, 214-227, 1996.

Alonso, J. L., Marcos, A., and Suárez, A.: Paleogeographic inversion resulting from large out of sequence breaching thrusts: The León Fault (Cantabrian Zone, NW Iberia). A new picture of the external Variscan Thrust Belt in the Ibero-Armorican Arc, Geol. Acta, 7, 451-473, doi:10.1344/105.000001449, 2009.

Álvarez-Marrón, J., Pérez-Estaún, A., Dañobeitia, J. J., Pulgar, J. A., Martínez Catalán, J. R. Marcos, A., Bastida, F., Ayarza, P.,
Arribas, J., Aller, J., Gallart, J., González-Lodeiro, F., Banda, E., Comas, M. C., and Córdoba, D.: Seismic structure of the northern continental margin of Spain from ESCIN deep seismic profiles, Tectonophysics, 264, 153-174, 1996.

Álvarez-Marrón, J., Rubio, E., and Torné, M.: Subduction-related structures in the North Iberian Margin, J. Geophys. Res., 102, 22497-22511, 1997.

Ayarza, P., Martínez Catalán, J. R., Gallart, J., Pulgar, J. A., and Dañobeitia, J. J.: Estudio Sísmico de la Corteza Ibérica Norte 3.3: A seismic image of the Variscan crust in the hinterland of the NW Iberian Massif, Tectonics, 18, 171-186, 1998.

Boillot, G. and Malod, J.: The north and northwest Spanish continental margin: a review, Revista de la Sociedad Geológica de España, 1, 295-316, 1988.

Boillot, G., Montadert, M., Lemoine, M., and Biju-Duval, B. (Eds.): Les marges continentales actuelles et fossiles autour de la France, Masson, Paris, 1984.

Bois, C., Gariel, O., and Pinet, B.: ECORS deep seismic surveys across Paleozoic and Mesozoic basins in France and adjacent areas: a review, in: The potential of deep seismic profiling for hydrocarbon exploration, edited by: Pinet, B. and Bois, C., Technip, Paris, 381-401, 1990.

Córdoba, D., Banda, E., and Ansorge, J.: P-wave velocity-depth distribution in the Hercynian crust of Northwest Spain, Phys. Earth Planet. In., 51, 235-248, 1988.

Dallmeyer, R. D. and Martínez-García, E. (Eds.): Pre-Mesozoic geology of Iberia, Springer-Verlag, New York, 1990.

Díaz, J. and Gallart, J.: Crustal structure beneath the Iberian Peninsula and surrounding waters: a new compilation of deep seismic sounding results, Phys. Earth Planet. In. 173, 181-190, doi:10.1016/j.pepi.2008.11.008, 2009.

Díaz, J., Gallart, J., Pedreira, D., Pulgar, J. A., Ruiz, M., López, C., and González-Cortina, J. M.: Teleseismic imaging of alpine crustal underthrusting beneath N-Iberia, Geophys. Res. Lett., 30, 1554, doi:10.1029/2003GL017073, 2003.

Díaz, J., Gallart, J., Pulgar, J. A., Ruiz, M., and Pedreira, D.: Crustal structure beneath North-West Iberia imaged using receiver functions, Tectonophysics, 478, 175-183, doi:10.1016/j.tecto.2009.08.003, 2009.

Díaz, J., Pedreira, D., Ruiz, M., Pulgar, J. A., and Gallart, J.: Mapping the indentation between the Iberian and Eurasian plates beneath the Western Pyrenees/Eastern Cantabrian Mountains from receiver function analysis, Tectonophysics, 570-571, 114-122, doi:10.1016/j.tecto.2012.07.005, 2012.

ECORS Pyrenees Team: The ECORS deep reflection seismic survey across the Pyrenees, Nature, 331, 508-511, 1988.

Espina, R. G., Alonso, J. L., and Pulgar, J. A.: Growth and propagation of buckle folds determined from syntectonic sediments (the Ubierna Fold Belt, Cantabrian Mountains, N Spain), J. Struct. Geol., 18, 431-441, 1996.

Fernández-Viejo, G.: Estructura cortical de la Cordillera Cantábrica y su transición a la Cuenca del Duero a partir de datos de sísmica de refracción/reflexión de gran ángulo, PhD Thesis, Universidad de Barcelona, España, 309 pp., 1997.

Fernández-Viejo, G. and Gallastegui, J.: The ESCI-N Project after a decade: A synthesis of the results and open questions Trabajos de Geología, Universidad de Oviedo, España, 25, 9-25, 2005.

Fernández-Viejo, G., Gallart, J., Pulgar, J. A., Gallastegui, J., Dañobeitia, J. J., and Córdoba, D.: Crustal transition between 
continental and oceanic domains along the North Iberian margin from wide angle seismic and gravity data, Geophys. Res. Lett., 25, 4249-4252, 1998.

Fernández-Viejo, G., Gallart, J., Pulgar, J. A., Córdoba, D., and Dañobeitia, J. J.: Seismic signature of Variscan and Alpine tectonics in NW Iberia: Crustal structure of the Cantabrian Mountains and Duero basin, J. Geophys. Res., 105, 3001-3018, 2000.

Fernández-Viejo, G., Gallastegui, G., Pulgar, J. A., and Gallart, J.: The MARCONI reflection seismic data: A view into the eastern part of the Bay of Biscay, Tectonophysics, 508, 34-41, doi:10.1016/j.tecto.2010.06.020, 2011.

Fernandez-Viejo, G., Pulgar, J. A., Gallastegui, J., and Quintana, L., The fossil accretionary wedge of the Bay of Biscay: critical wedge analysis on depth-migrated seismic sections and geodynamical implications, J. Geol., 120, 315-33, doi:10.1086/664789, 2012.

Gallart, J., Fernández-Viejo, G., Díaz, J., Vidal, N., and Pulgar, J. A.: Deep structure of the transition between the Cantabrian Mountains and the North Iberian Margin from wide angle ESCIN-N data, Revista de la Sociedad Geológica de España, 8, 365-382, 1995.

Gallastegui, J.: Estructura cortical de la cordillera y margen continental cantábricos: perfiles ESCI-N, PhD Thesis, Trabajos de Geología, Universidad de Oviedo, España, 22, 220 pp., 2000.

Gallastegui, J., Pulgar, J. A., and Álvarez-Marrón, J.: 2-D seismic modelling of the Variscan foreland thrust and fold belt in NW Spain from ESCIN-1 deep seismic reflection data, Tectonophysics, 269, 21-32, 1997.

Gallastegui, J., Pulgar, J. A., and Gallart, J.: Initiation of an active margin at the North Iberian continent-ocean transition, Tectonics, 21, 15-1-15-14, doi:10.1029/2001TC901046, 2002.

García-Ramos, J. C., Colmenero, J. R., Manjón, M., and Vargas, I.: Modelo de sedimentación en los abanicos aluviales de clastos carbonatados del borde $\mathrm{N}$ de la Cuenca del Duero, Temas Geológico-Mineros, IGME, 6, 275-289, 1982.

Gutiérrez-Claverol, M., Rodríguez-Bouzo, L., Sánchez-Fernández, B., and Torres-Alonso, M.: Relationship between joint density and Pwave velocity in rock units of the Cantabrian Zone (NW Spain), in: Proceedings of the 7th International Congress of the International Association of Engineering Geology, Lisboa, 2, 787-795, 1994.

Julivert, M.: Decollement tectonics in the Hercynian Cordillera of NW Spain, Am. J. Sci., 270, 1-29, 1971.

Llana-Fúnez, S. and López-Fernández, C.: The seismogenic zone of the continental crust in Northwest Iberia and its relation to crustal structure, Tectonics, 34, 1751-1767, doi:10.1002/2015TC003877, 2015.

López Olmedo, F., Enrile, A., and Cabra, P.: Memoria explicativa de la Hoja no. 133 (Prádanos de Ojeda) del Mapa Geológico Nacional a escala 1:50.000, Segunda Serie MAGNA, Primera Edición, ITGE, Madrid, 1997.

Matte, P.: Accretionary history and crustal evolution of the Variscan belt in Western Europe, Tectonophysics, 196, 309-337, 1991.

Marín, J. A.: Estructura del Domo de Valsurbio y borde suroriental de la región del Pisuerga-Carrión (Zona Cantábrica, NO España), PhD Thesis, Oviedo University, Spain, 181 pp., 1997.

Martín-González, F., Barbero, L., Capote, R., Heredia, N., and Gallastegui, G.: Interaction of two successive Alpine deformation fronts: constraints from low-temperature thermochronology and structural zapping (NW Iberian Peninsula), Int. J. Earth Sci., 101, 1331-1342, doi:10.1007/s00531-011-0712-9, 2011.

Martín-González, F., Freudenthal, M., Heredia, N., Martín-Suárez, E., and Rodríguez-Fernández, R.: Palaontological age and correlations in the Tertiary deposits of the NW Iberian Peninsula: the tectonic evolution of a broken foreland basin, Geol. J., 49, 15-27, doi:10.1002/gj.2484, 2014.

Martínez-García, E.: El Pérmico de la región Cantábrica, in: Carbonífero y Pérmico de España, edited by: Martínez-Díaz, E., Instituto Geológico Minero España, 389-402, 1982.

Mooney, W. D. and Meissner, R.: Multi-generic origin of crustal reflectivity: A review of seismic reflection profiling of the continental lower crust and Moho, in: Continental lower crust, edited by: Fountain, D. M., Arculus, R., and Kay, R. W., Elsevier, Amsterdam, 45-79, 1992.

Muñoz, J. A.: Evolution of a continental collision belt: ECORSPyrenees crustal balanced cross-section, in: Trust and nappe tectonics, edited by: McClay, K. R. and Price, N. J., Chapman and Hall, London, 235-246, 1992.

Pedreira, D., Pulgar, J. A., Gallart, J., and Díaz, J.: Seismic evidence of Alpine crustal thickening and wedging from the western Pyrenees to the Cantabrian Mountains (north Iberia), J. Geophys. Res., 108, 2204, doi:10.1029/2001JB001667, 2003.

Pedreira, D., Pulgar, J. A., Gallart, J., and Torné, J.: 3D gravity and magnetic modelling of crustal indentation and wedging in the western Pyrenees-Cantabrian Mountains, J. Geophys. Res., 112, B12405, doi:10.1029/2007JB005021, 2007.

Pedreira, D., Afonso, J. C., Pulgar, J. A., Gallastegui, J., Carballo, A., Fernández, M., García-Castellanos, D., Jiménez-Munt, I., Semprich, J., and García-Moreno, O.: Geophysical-petrological modelling of the lithosphere beneath the Cantabrian Mountains and North-Iberian margin: geodynamic implications, Lithos, 230, 46-68, doi:10.1016/j.lithos.2015.04.018, 2015.

Pérez-Estaún, A. and Bastida, F.: Cantabrian Zone, in: PreMesozoic geology of Iberia, edited by: Dallmeyer, R. D. and Martínez García, E., Springer-Verlag, Berlin, 55-69, 1990.

Pérez-Estaún, A., Bastida, F., Alonso, J. L., Marquínez, J., Aller, J., Álvarez-Marrón, J., Marcos, A., and Pulgar, J. A.: A thinskinned tectonics model for an arcuate fold and thrust belt: the Cantabrian Zone (Variscan Ibero-Armorican Arc), Tectonics, 7, 517-537, 1988.

Pérez-Estaún, A., Pulgar, J. A., Banda, E., Álvarez-Marrón, J., and ESCI-N Research Group: Crustal structure of the external Variscides in Northwest Spain from deep seismic reflection profiling, Tectonophysics, 232, 91-118, 1994.

Portero García, J. M., del Olmo Zamora, P., Ramírez del Pozo, J., and Vargas Alonso, I.: Síntesis del Terciario continental de la Cuenca del Duero. Temas Geológicos Mineros, Instituto Geológico y Minero de España, 6, 11-40, 1982.

Pous, J. Queralt, P., and Marcuello, A.: Magnetotelluric signature of western Cantabrian Mountains, Geophys. Res. Lett., 28, 17951798, 2001.

Pulgar, J. A., Pérez-Estaún, A., Gallart, J., Álvarez-Marrón, J., Gallastegui, J., Alonso, J. L., and ESCIN Group: The ESCIN-2 deep seismic reflection profile: a traverse across the Cantabrian Mountains and adjacent Duero basin, Revista Sociedad Geológica España, 8, 383-394, 1995.

Pulgar, J. A., Gallart, J., Fernández-Viejo, G., Pérez-Estaún, A., Álvarez-Marrón, J., and ESCIN Group.: Seismic image of the 
Cantabrian Mountains in the western extension of the Pyrenees from integrated ESCIN reflection and refraction data, Tectonophysics, 264, 1-19, 1996.

Pulgar, J. A., Alonso, J. L., Espina, R. G., and Marín, J. A.: La deformación alpina en el basamento varisco de la Zona Cantábrica, Trabajos de Geología, Universidad Oviedo, España, 21, 283-294, 1999.

Rodríguez-Fernández, L. R.: La estratigrafía del Paleozoico y la estructura de la región de Fuentes Carrionas y áreas adyacentes (Cordillera Herciniana, NO España), Serie Nova Terra, 9, Laboratorio Xeolóxico de Laxe, A Coruña, 240 pp., 1994.

Smithson, S. B., Brewer, J. A., Kaufman, S., Oliver, J. E., and Hurich, C. A.: Structure of the Laramide Wind River Uplift, Wyoming, from COCORP deep reflection data and from gravity data, J. Geophys. Res., 84, 5955-5972, 1979.
Teixell, A.: Crustal structure and orogenic material budget in the west central Pyrenees, Tectonics, 17, 395-406, 1998.

Vegas, R. and Banda, E.: Tectonic framework and Alpine evolution of the Iberian Peninsula, Earth Evolution Sciences, 4, 320-342, 1982.

Verhoeff, J. and Srivastava, S. P.: Correlation of sedimentary basins across the North Atlantic as obtained from gravity and magnetic data, and its relation to the early evolution of the North Atlantic, in: Extensional tectonics and Stratigraphy of the North Atlantic margins, edited by: Tankard, A. J. and Balkwill, H. R., AAPG Memoir, 46, 131-147, 1989. 